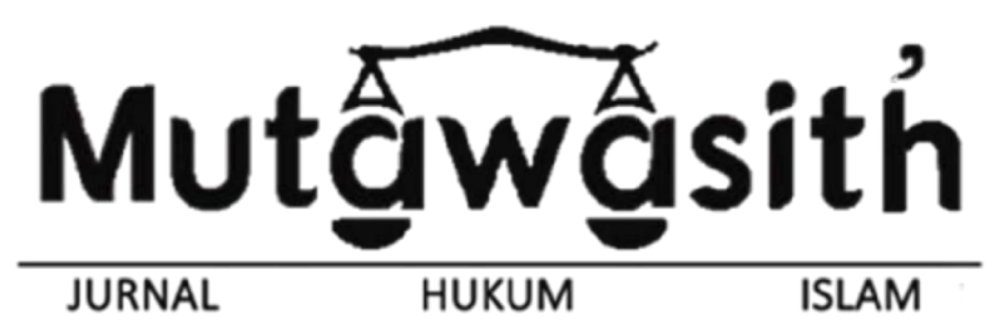

\title{
MEKANISME PENYELESAIAN SENGKETA MURABAHAH DI PENGADILAN AGAMA KOTA TASIKAMALAYA
}

(Analisis Putusan No. 1062/Pdt.G/2016/PA.Tmk. )

\author{
Suaib Lubis, Mahpudin, Muhamad Dani Somantri \\ Fakultas Syariah, Institut Agama Islam Latifah Mubarokiyah Tasikmalaya, Indonesia \\ STAI Jam'iyah Mahmudiyah Tanjung Pura Langkat, Indonesia \\ Email: pudin.suryalaya@gmail.com, Suaib_Lubis@staijm.ac.id, \\ muhamaddanisomantri34@gmail.com
}

\begin{abstract}
Abstrak
Kegiatan Bank Perkreditan Rakyat Syariah yaitu menghimpun dana dan menyalurkan dana. Sejalan dengan kegiatan Bank Perkreditan Rakyat Syariah dalam pelaksanaan pembiayaan. Hal yang sering menjadi kendala ialah telatnya nasabah dalam membayar angsuran (wanprestasi), maka timbulah persengketaan antara pihak yakni PT. Bank Perkreditan Rakyat Syariah Al-Wadiah dengan nasabahnya. Tujuan penelitian ini mengetahui mekanisme penyelesaian sengketa wanprestasi dan dasar hukum dan pertimbangan hakim dalam memutuskan perkara. Metode yang digunakan deskriptif analisis content mengenai fakta-fakta yang diselidiki. Teknik pengumpulan data dengan wawancara kemudia dicatat atau direkam. Analisis data dilakukan dengan pendekatan kualitatif. Hasilnya menunjukan bahwa persengketaan antara kedua pihak murni kelalaian nasabah selaku debitur yang tak bisa menunaikan kewajibannya, kemudian dalam proses penyelesaiannya di Pengadilan Agama telah sesuai dengan mekanisme beracara di Peradilan Agama sebagaimana tertuang pada Undang-Undang No. 03 tahun 2006 tentang Peradilan Agama dan Undang-Undang No. 21 tahun 2008 tentang Perbankan Syariah. Dasar hukum pertimbangan hakim memutuskan perkara No. 1062/Pdt.G/2016/PA.Tmk adalah Kompilasi Hukum Ekonomi Syariah (KHES), KHUPerdata, Yurisprudensi, Undang-Undang No. 40 Tahun 2007 Pasal 98 Tentang Perseroan Terbatas.
\end{abstract}

Kata Kunci: sengketa, murabahah, pengadilan agama.

\section{Abstract}

Activities of Sharia Rural Banks, namely raising funds and channeling funds. In line with the activities of Sharia Rural Banks in the implementation of financing. The thing that often becomes an obstacle in these activities is the late customer in paying installments (default), from this, the emergence of sharia economic disputes between the two parties. As a sharia economic dispute between PT. Al-Wadiah Sharia Rural Bank and its customers. The purpose of this study is to find out mechanism of dispute resolution dispute and the legal basis and consideration of the judge in deciding the case.The method used is descriptive content analysis of the facts investigated. The technique of data collection is by way of interviews by recording or recording. Data 
analysis was carried out with a qualitative approach. It was concluded that the dispute between the two parties was pure negligence of the customer as a debtor who could not fulfill his obligations, then in the process of settlement in the Religious Court in accordance with the mechanism of proceedings in the Religious Courts as stated in Law No. 03 of 2006 concerning the Religious Courts and Law No. 21 of 2008 concerning Islamic Banking. The legal basis for judges' consideration in deciding case No. 1062 / Pdt.G / 2016 / PA.Tmk is the Compilation of Sharia Economic Law (KHES), KHUPerdata, Jurisprudence, Law No. 40 of 2007 Article 98 concerning Limited Liability Company, Fatwa

Keywords: disputes, murabahah, religious courts.

\section{PENDAHULUAN}

Islam hadir sebagai sumber kekuatan yang baru pada Abad ke-7 Masehi, menyusul runtuhnya kekaisaran romawi. Kemunculan itu ditandai dengan berkembangnya peradaban baru yang sangat mengagumkan. Kebudayaan, ilmu pengetahuan, dan teknologi serta kehidupan sosial lainnya termasuk ekonomi yang berkembang secara menakjubkan. ${ }^{1}$

Dewasa ini perkembangan arus globalisasi ekonomi dunia dan kerjasama di bidang perdagangan kian berkembang sangat pesat. Kehidupan ekonomi telah menjadi standar kehidupan individu dan kolektif suatu negara-bangsa. Dalam menjalankan kehidupan manusia tidak lepas dari masalah kebutuhan pokok (sandang, pangan, dan papan). Kebutuhan pokok tersebut hanya dapat diperoleh dengan melakukan usaha, baik dengan cara individu maupun kelompok. Oleh karena itu ilmu ekonomi menjadi sangat penting bagi kehidupan suatu bangsa. Pakar ilmu ekonomi Sekaliber Marshal menyatakan bahwa kehidupan dunia ini dikendalikan oleh dua kekuatan besar, yaitu ekonomi dan keimanan (agama). ${ }^{2}$

Di Indonesia, salah satu faktor pertumbuhan ekonomi dapat dilihat dari pertumbuhan dari sektor lembaga keuangan khususnya pada sektor perbankan. Hadirnya perbankan syariah di akhir abad ke-20 menjadi jawaban atas usaha kerja tim Majlis Ulama Indonesia (MUI), melihat mayoritas masyarakat Indonesia adalah Islam. Ekonomi Islam sesungguhnya merupakan konsekuensi biologis dari Islam itu sendiri. Sistem ekonomi Islam merupakan sistem ekonomi yang mandiri dan dibangun berdasarkan nilai-nilai etika dan moralitas keagamaan yang bersumber kepada Alquran, sunnah dan ijtihad.

${ }^{1}$ Mustafa Edwin Nasution, dkk, Pengenalan Ekslusif Ekonomi Islam, cet. Ke-6 (Jakarta: Prenadamedia Group, 2006), hlm. 1.

2 Juhaya S.Pradja, Ekonomi Syariah, (Bandung: CV Pustaka Setia, 2012), hlm. 39. 
Dengan berkembangnya ilmu pengetahuan dan teknologi maka menuntut pula perkembangan sistem ekonomi Islam yang diimplementasikan dalam bentuk pendirian lembaga keuangan syariah baik bank maupun non bank. Filsafat ekonomi Islam menjadi salah satu landasan operasional dalam lembaga keuangan syariah. Sebagaimana disahkannya Undang-Undang nomor 7 tahun 1992 Tentang Perbankan, dan mendirikan bank Muamalat Indonesia (BMI) sebagai bank syariah yang beroperasi pertama di Indonesia.

Lahirnya BMI ini, menjadi langkah upaya penguatan perekonomian Indonesia khusus perbankan syariah yang bertujuan untuk memberikan kesejahteraan rakyat yang lebih baik. Mengingat pada masa pendirian BMI tidak lama kemudian terjadi krisis moneter yang menimbulkan ketidak seimbangan perekonomian global. Banyak bank yang dengan modal banyak maupun kecil mengalami negative spread sehingga muncul kenyataan bank sudah tutup dengan kerugian ratusan triliun. BMI menjadi salah satu bank yang bertahan pada perhelaan krisis moneter di tahun 1998. Dan ini menjadi salah satu bukti bahwa ekonomi syariah menjadi jaminan sosial bagi rakyat Indonesia. Maka dengan seiring itu perkembangan perbankan syariah pada era reformasi ini ditandai dengan disetujuinya Undang-Undang No. 10 Tahun 1998 tentang Perubahan Atas Undang-Undang No. 7 Tahun 1992 Tentang Perbankan.

Saat ini perkembangan ekonomi syariah di Indonesia mengalami kemajuan yang sangat pesat, dengan berdirinya lembaga keuangan lainnya yang menerapkan prinsip syariah, seperti asuransi syariah, pasar modal syariah, reksadana syariah. pegadaian syariah, dan lembaga pembiayaan syariah. Dalam operasionalnya perbankan syariah menggunakan prinsip syirkah, al-mudharabah, bai-assalam, baial isthisna, bai'-al Murabahah, al-ijarah, al - hawalah, ar-rahn, alwakalah, alkafalah, dan al-qard. Yang semuanya itu menggunakan filosofis utama kemitraan dan kebersamaan (sharing) dalam profit dan risk, dengan tujuan untuk mewujudkan kegiatan ekonomi yang adil dan transparan. Industri perbankan syariah memiliki kombinasi sistem komersial dan multifinance yang lebih menekankan kepada mekanisme pembiayaan syariah.

Pembiayaan syariah merupakan bentuk pinjaman yang hampir sama dengan kredit konvensional. Langkah awal yang harus ditempuh dalam pemberian fasilitas pembiayaan adalah menganalisis terhadap kondisi keuangan nasabah yang tujuan untuk memprediksi kemampuan nasabah dalam mengambalikan pinjamannya. Seiring berjalannya waktu lembaga keuangan syariah baik bank maupun non bank, maka semakin banyak masyarakat pelaku usaha mengaitkan dirinya dalam suatu kegiatan menyimpan dana dan kegiatan perjanjian. Salah satunya lembaga 
keuangan yang melakukan kegiatan perbankan syariah yaitu PT. Bank Pembiayaan Rakyat Syariah Al-Wadiah (BPRS Al-Wadiah).

Dalam melaksanakan kegiatan sebagai lembaga keuangan Bank BPRS AlWadiah banyak melakukan kegiatan pembiayaan kepada para nasabahnya dengan berbagai akad. Akan tetapi sejalan dengan pembiayaan yang dilakukan Bank BPRS Al-Wadiah Kota Tasikmalaya tidak sedikit pula nasabahnya yang beringkar janji (wanprestasi), tidak melakukan pembayaran tepat waktu sebagaimana yang ajukan Bank BPRS Al-Wadiah kepada Tergugatnya dalam hal ini bertindak sebagai 

"Penggugat" melawan saudara Gusnandang, S.Pd. Sebagai "Tergugat I", saudari Tatat Yulianti, sebagai "Tergugat II" dan Pemerintah Kota Tasikmalaya cq. Dinas Pendidikan Kota Tasikmalaya cq. Kepala Sekolah SMPN 10 Kota Tasikmalaya. Sebagai "Tergugat III".

Bahwa Tergugat I telah sepakat melakukan perjanjian pembiayaan dengan Penggugat dan diketahui oleh Tergugat II yang kemudian memberikan persetujuan kepada Tergugat I dengan bukti surat pernyataan istri dan dinyatakan perkara a quo. Juga pihak Tergugat III, sepakat dan setuju untuk mengikatkan diri dalam perjanjian pembiayaan antara Penggugat dan Tergugat I dengan pernyataan tertulis Tergugat III. Namun seiring berjalannya waktu, Tergugat I tidak lancar dalam melakukan pembayaran kepada Penggugat, padahal mendapat penghasilan tetap yang terukur dan pasti dari gaji yang diterimanya.

Hingga pada suatu waktu Tergugat I tidak melakukan pembayaran sama sekali kepada Penggugat. Dan Penggugat telah melakukan upaya persuasif melalui surat peringatan (somasi), namun tidak adanya respon positif Tergugat I. juga Tergugat III yang telah mendapatkan kuasa dari Terugat I yang pokoknya akan memotong gaji/penghasilan dan atau tunjangan-tunjangan Tergugat I namun tidak menyetorkannya dan patut dinyatakan lalai.

Setelah melihat beberapa penjelasan di atas bahwasannya di dalam penyelesaian sengketa hukum ekonomi syariah, kewenangan untuk menyelesaikan perkara ekonomi syariah bukan lagi dilakukan oleh Pengadilan Negeri (umum) akan tetapi dilakukan oleh Pengadilan Agama sebagaimana yang termaktub dalam Undang-Undang No. 3 Tahun 2006 yang menegaskan bahwa Pengadilan Agama bertugas dan berwenang memeriksa, memutuskan, dan menyelesaikan perkara tingkat pertama. Antara orang-orang yang beragama Islam di bidang perkawinan, waris, wasiat, hibah, wakaf, zakat, infak, shadaqah, dan ekonomi syariah.

Dengan itu kewenangan Pengadilan Agama diperluas termasuk dalam bidang penyelesaian sengketa ekonomi syariah, meliputi: sengketa bank syariah, sengketa Lembaga Keuangan Mikro Syariah, sengketa asuransi syariah, sengketa reasuransi syariah, sengketa reksadana syariah, sengketa obligasi syariah, sengketa sekuritas syariah, sengketa pembiayaan syariah, sengketa pegadaian syariah, sengketa dana pensiun lembaga keuangan syariah, dan sengketa bisnis syariah.

Penelitian ini bertujuan untuk mengetahui mekanisme penyelesaian sengketa wanprestasi di Pengadilan Agama; mengetahui proses penyelesaian sengketa wanprestasi Murabahah di Pengadilan Agama Kota Tasikmalaya antara 
PT. Bank Pembiayaan Rakyat Syariah Al-Wadiah dengan Nasabah; dan pertimbangan Hakim dalam memutus No: 1062/Pdt/G/2016/PA.Tmk.

\section{METODOLOGI PENELITIAN}

\section{Metode Penelitian}

Penelitian ini disusun berdasarkan metode deskriptif analisis content. Jenis datanya deskriptif kualitatif. Penelitian kualitatif merupakan penelitian yang menggunakan latar alamiah, dengan maksud menafsirkan fenomena yang terjadi dan dilakukan dengan jalan melibatkan berbagai metode yang ada. ${ }^{3}$

\section{Sumber Data}

Sumber data primer: data yang diperoleh peneliti langsung dari hasil penelitian dan penyelidikan secara langsung di lapangan dalam hubungannya dengan materi yang dibahas. Sumber data Sekunder: dari data dokumen dan dengan melakukan studi pustaka melalui buku, artikel, jurnal, internet dan sumber lainnya.

\section{Teknik Pengumpulan Data}

Wawancara (Interview) Wawancara adalah suatu proses pengumpulan data atau informasi melalui tatap muka antara pihak penanya (interviewer) dengan pihak yang ditanya atau penjawab (interviewee). Wawancara dalam penelitian kualitatif sifatnya mendalam karena ingin mengeksplorasi informasi secara holistik dan jelas dari informan. Telaah Pustaka, pustaka yang digunakan dalam penelitian ini adalah literatur yang ada kaitannya dengan penelitian ini atau dokumen serta media yang mendukung.

\section{Teknik Analisis Data}

Dalam usaha mencari jawaban dari masalah yang ada maka dipergunakan metode: Deskriptif, yaitu suatu metode dalam suatu penelitian yang digunakan untuk menggambarkan dan memaparkan mengenai suatu objek, fenomena, atau setting sosial yang tertuang dalam suatu tulisan yang bersifat naratif.

\footnotetext{
hlm. 23.

${ }^{3}$ Djam'an Satori dan Aan Komariah,, Metodologi Penelitian Kualitatif, (Bandung: Alfabeta, 2011),
} 
Menggunakan Pola Berfikir Induktif, yaitu proses pendekatan yang dimulai dengan pernyataan-pernyaataan spesifik dari fakta khusus. Cara kerja induktif tidak seperti menyusun mozaik yang bentuk akhirnya sudah diketahui, tetapi menemukan bentuk utuh dan bermakna hasil dari gambar-gambar yang ditemukan pada saat mengumpulkan data. Peneliti menemukan data/fakta-fakta secara khusus atau bagian-bagian yang setelah dianalisis dan disintesiskan menghasilkan suatu kesimpulan.

\section{PEMBAHASAN HASIL PENELITIAN}

Dalam Undang-Undang Nomor 7 Tahun 1989 sebagaimana telah dirubah dengan Undang-Undang Nomor 3 Tahun 2006 dan Perubahan kedua dengan Undang-Undang No. 50 Tahun 2009 Tentang Peradilan Agama, memberikan kewenangan bagi Pengadilan Agama untuk menangani perkara sengketa ekonomi syariah sebagimana termaktub pada Pasal 49 yang berbunyi: Pengadilan Agama bertugas dan berwenang memeriksa, memutus, dan menyelesaikan perkara tingkat pertama antara orang-orang yang beradama Islam di bidang: perkawinan; waris; wasiat; hibah; wakaf; zakat; infaq; shadaqah; dan ekonomi syariah.

Atas dasar undang-undang tersebut, Penggugat mengajukan gugatan ke Pengadilan Agama Kota Tasikmalaya dengan tuduhan bahwa Tergugat telah melakukan wanprestasi perjanjian pembiayaan murabahah. Selain dari pada hak kewenangan absolut Pengadilan Agama, Penggugat juga mendasarkan gugatannya pada isi surat perjanjian berdasarkan Pasal 17 ayat 17.2 Surat Perjanjian Pembiayaan Al Murabahah P.P No: 01057/Pem/m84/02/2011 yang menjelaskan tentang kesepakatan para pihak yang mengikatkan diri pada perjanjian, jika dikemudian hari terjadi sengketa, maka mereka sepakat menyeleaikaan perkara sengketa ekonomi syariah tersebut di Pengadilan Agama Kota Tasikmalaya.

Pengadilan Agama bukanlah satu-satunya institusi atau jalan dalam penyelesaikan perkara sengketa ekonomi syariah. Para pihak yang berakad tentunya dapat menempuh jalur non litigasi, yaitu penyelesaian sengketa di luar peradilan, seperti Tahkim dan meminta tolong BASYARNAS. Penyelesaian sengketa non litigasi hanya dapat terjadi ketika para pihak pembuat akad menyertakan klausul tersebut dalam perjanjian. Hal demikian termaktub dalam Undang-undang No. 21 Tahun 2008 Tentang Perbankan Syariah Pasal 55 yang berbunyi:

1. Penyelesaian sengketa Perbankan Syariah dilakukan oleh pengadilan dalam lingkungan Peradilan Agama. 
2. Dalam hal para pihak telah meperjanjikan penyelesaian sengketa selain sebagaimana dimaksud pada ayat (1), penyelesaian sengketa dilakukan seuai dengan isi akad.

3. Penyelesaian sengketa sebagaimana dimaksudkan pada ayat (2) tidak boleh bertentangan dengan Prinsip Syariah.

Gugatan yang diajukan Penggugat kepada Para Tergugat bukanlah tanpa kekurangan, setidaknya peneliti menemukan dua kekurangan dalam gugatan ini. Pertama, penulisan jangka waktu pembayaran sejumlah 48 (empat puluh delapan) terhitung sejak tanggal 10 maret 2011 sampai 10 februari 2014. Peneliti menghitung jangka waktu 10 maret 2011 sampai 10 februari 2014 adalah 36 bulan dan 48 bulan bila mencapai pada taggal 10 februari 2015. Kekeliruan ini mestinya tidak terjadi guna meneguhkan ketelitian Penggugat dalam mengajukan gugatan dan tidak memberikan arti lain meskipun dapat diperbaiki atas dasar kehilafan, sesuai Pasal 1344 dan Pasal 1345 KHUPerdata, maka jangka waktu yang paling memungkinkan dan arti yang paling sesuai adalah arti yang didukung oleh surat-surat atau akta-akta lain yang merupakan bagian yang tidak terpisah dalam surat perjanjian. 
Kedua, penggunaan istilah "bunga" dalam kegiatan ekonomi syariah tidaklah tepat. Karena ekonomi syariah merupakan kegiatan perekonomian yang mengedepankan prinsip syariah. Peneliti telah menjelaskan di bab sebelumnya bahwa murabahah termasuk kegiatan jual beli dan atau perjanjian pembiayaan dengan mengambil keuntungan (margin) sesuai kesepakatan yang pembayarannya dilakukan secara kontan maupun kredit. Sedangkan bunga adalah bagian dari bank konvensional dalam kegiatan pinjaman dan perhimpunan dana dengan besar persentase bunga dikaitkan dengan jumlah uang yang dipinjam. Dalam perbankan syariah tidak dikenal istilah bunga, oleh karena bunga adalah riba yang diharamkan dalam syariat Islam sebagaimana Q.S Al Baqarah ayat 275 :

"Dan Allah telah menghalalkan jual beli dan mengharamkan riba." [AlBaqarah: 275]

Pertimbngan hukum lain yang digunakan Hakim dalam memutuss perkara ini adalah Undang-Undang Nomor 21 Tahun 2008 Tentang Perbankan Syariah. Dan Undang-Undang Nomor 40 Tahun 2007 Pasal 98 Tentang Perseroan Terbatas yang berbunyi: Undang-Undang ini pada dasarnya menganut sistem perwakilan kolegial, yang berarti tiap-tiap anggota Direksi berwenang mewakili Peseroannya. Namun, untuk kepentingan Perseroan, anggaran dasar dapat menentukan bahwa Perseroan diwakili oleh anggota Direksi tertentu.

Yurisprudensi Mahkamah Agung RI Nomor 2332.K/Pdt/1985, Penggugat memiliki kewenangan atau memiliki legitimasi persona standi injudicio untuk mewakili pihak bank dalam mengajukan gugatan kepara para tergugat. Pertimbangan hukum lainnya adalah Kompilasi Hukum Ekonomi Syariah (KHES). KHES merupakan dasar pertimbangan hukum pertama dalam kasus sengketa ekonomi syariah sebagaimana Peraturan Mahkamah Agung RI No. 2 Tahun 2008 dan Fatwa Dewan Syariah Nasional No. 04/DSN-MUI/IV/2000, tentang murabahah.

KHES sendiri dikeluarkan oleh Mahkamah Agung RI dalam upaya menjawab atas berkembangnya praktek ekonomi syariah di Indonesia khususnya perbankan syariah. Demikian juga dengan putusan No 1062/Pdt.G/2016/PA. Tmk ini menggunakan KHES sebagai pertimbangan hukum yang paling pertama. Pasal-pasal yang digunakan oleh Hakim sebagai pertimbangan hukum adalah: Pasal 20, Pasal 22 s.d 25, dan Pasal 124. Sebagaimana peneliti ketahui di dalam KHES Pasal 20 ini memiliki 46 ayat, yang seharusnya dapat diperjelas kembali dengan 
mencantumkan ayat pasal yang berkaitan dengan perkara ini (akad murabahah) Ayat (1) dan (6).

Pasal 20 ayat (1) dan (6) KHES menyangkut definisi akad dan murabahah. Bunyi pasal tersebut ialah: (1) Akad adalah kesepakatan dalam suatu perjanjian antara dua pihak atau lebih untuk melakukan dan atau tidak melakukan perbuatan hukum tertentu. Murabahah adalah pembiayaan saling menguntungkan yang dilakukan oleh shahib al-mal dengan pihak yang membutuhkan melalui transaksi jual beli dengan penjelasan bahwa harga pengadaan barang dan harga jual terdapat nilai lebih yang merupakan keuntungan atau laba bagi shahib al-mal dan pengembaliannya dilakukan secara tunai atau angsur.

Penggunaan pasal ini sebagai pertimbangan hukum sudah sepatutnya dipergunakan, guna mengetahui akad tersebut memenuhi syarat dan rukun tidaknya yang telah disepakati antara Penggugat dan Tergugat dalam membuat kesepakatan akad perjanjian pembiayaan murabahah

No.01057/Pem/m84/02/2011. Pasal 22 KHES menjelaskan rukun akad. Demikian bunyi pasal tersebut adalah:

Rukun akad terdiri atas:

a. Pihak-pihak yang berakad;

b. Obyek akad;

c. Tujuan-pokok akad; dan

d. kesepakatan.

Pasal 23 KHES menjelakan tentang pihak-pihak yang berakad. Bunyi pasal tersebut adalah: Pihak-pihak yang berakad adalah orang, persekutuan, atau badan usaha yang memiliki kecakapan dalam melakukan perbuatan hukum. Pasal 24 KHES menjelakan objek akad. Bunyi ayat tersebut adalah: Obyek akad adalah amwal atau jasa yang dihalalkan yang dibutuhkan oleh masing-masing pihak. Pasal 25 KHES menjelaskan tentang tujuan berakad. Bunyi ayat tersebut adalah: Akad bertujuan untuk memenuhi kebutuhan hidup dan pengembangan usaha masing-masing pihak yang mengadakan akad.

Dari semua yang terdapat pada Pasal 22 s.d 25 KHES, kesemuanya sudah dipenuhi dalam akad perjanjian pembiayaan murabahah No.01057/Pem/m84/02/2011. Para pihak yang berakad adalah Penggugat dan para Tergugat yang semuanya telah cakap hukum, berakal dan tamyiz. Objek akad adalah barang yang suci dan bermanfaat, yaitu uang. Tujuan pokok akad adalah sebagai modal renovasi rumah. Dan kesepakatan adalah kesanggupan 
dari kedua belah pihak dalam menjalankan isi akad. Pasal 124 KHES menjelaskan tentang sistem pembayaran. Bunyi pasal tersebut adalah:

(1) Sistem pembayaran dalam akad murabahah dapat dilakukan secara tunai atau cicilan dalam kurun waktu yang disepakati.

(2) Dalam hal pembeli mengalami penurunan kemampuan dalam pembayaran cicilan, maka ia dapat diberi keringanan.

(3) Keringanan sebagaimana dimaksud pada ayat (2) di atas dapat diwujudkan dalam bentuk konversi dengan membuat akad baru dalam penyelesaian kewajiban.

Inti dari pasal tersebut adalah menjelaskan tantacara pembayaran yang harus dilakukan oleh pihak meminjam (debitur) kepada pihak peminjam (kreditur) sesuai akad yang disepakati. Pada akad perjanjian pembiayaan murabahah No.01057/Pem/m84/02/2011 disepakati bahwa pembayaran dilakukan setiap bulan pertanggal 10 (sepuluh).

Pertimbangan hukum lainnya yang digunakan Hakim adalah Pasal 1801 KHUPerdata tentang penerima kuasa. Bunyi pasal tersebut adalah:

Penerima kuasa tidak hanya bertanggung jawab atas perbuatan-perbuatan yang dilakukan dengan sengaja melainkan juga atas kelalaian-kelalaian yang dilakukan dalam menjalankan kuasanya. Akan tetapi tanggung jawab atas kelalaiankelalaian orang dengan Cuma-Cuma menerima kuasa, tidaklah seberat bertanggung jawab yang diminta dari orang menerima kuasa dengan mendapat upah.

Pertimbangan hukum lainnya adalah Pasal 1243 s.d 1246 KHUPerdata jo. Bunyi pasal tersebut adalah:

\section{Pasal 1243}

Pengganti biaya, kerugian dan bunga karena tak dipenuhinya suatu perikatan mulai diwajibkan, bila debitur, walaupun telah dinyatakan lalai, tetap lalai untuk memenuhi perikatan itu, atau jika suatu yang harus diberikan atau dilakukannya hanya dapat diberikan atau dilakukannya dalam waktu yangmelampaui waktu yang telah ditentukan.

Pasal 1244

Debitur harus dihukum untuk mengganti biaya, kerugian dan bunga. Bila ia tidak dapat membuktikan bahwa tidak dilaksanakannya perikatan itu atau tidak tepatnya waktu dalam melaksanakan perikatan itu disebabkan oleh sesuatu hal yang tak terduga, yang tak dapat dipertanggungkan kepadanya, walaupun tidak ada itikad buruk kepadanya. 


\section{Pasal 1245}

Tidak ada penggantian biaya, kerugian dan bunga. Bila semua keadaan memaksa atau hal yang terjadi secara kebetulan, debitur terhalang untuk memberikan atau berbuat sesuatu yang diwajibkan, atau melakukan suatu perbuatan yang terlarang baginya.

Pasal 38 KHES tentang sanksi bagi pihak yang ingkar janji. Bunyi pasal tersebut adalah:

Pihak dalam akad yang melakukan ingkar janji dapat dijatuhi sanksi:

a. Membayar ganti rugi;

b. pembatalan akad;

c. peralihan resiko;

d. denda; dan/atau

e. membayar biaya perkara.

Pasal 19 Peraturan Bank Indonesia Nomor 7/46/PBI/2005 tentang Akad Perhimpunan dan Penyaluran Dana Bagi Bank Yang Melaksanakan Kewajiban Usaha Berdasarkan Prinsip Syariah. Bunyi pasal tersebut adalah: Ketentuan ganti rugi ( $\left.t a^{\prime} w i d h\right)$ dalam pembiayaan:

a. Bank dapat mengenakan ganti rugi (ta'widh) hanya atas kerugian rill yang dapat diperhitungkan dengan jelas kepada nasabah yang dengan sengaja atau karena kelalalian melakukan sesuatu yang menyimpang dari ketentuan akad dan mengakibatkan kerugian pada Bank;

b. Besar ganti rugi yang dapat diakui sebagai pendapatan Bank adalah sesuai dengan nilai kerugian rill (real loss) yang berkaitan dengan upaya Bank untuk memperoleh pembayaran dari nasabah dan bukan kerugian yang diperkitakan akan terjadi (potential loss) karena adanya peluang yang hilang (oppotunity loss/al-fushah al-dha-i'ah);

c. Ganti rugi hanya boleh dikenakan pada Akad Ijarah dan Akad yang menimbulkan utang piutang (dain), seperti Salam, Istishna' serta Murabahah, yang pembayarannya dilakukan tidak secara tunai.

Fatwa Dewan Syariah Nasional No. 17/DSN-MUI/IX/2000 tentang Sanksi Atas Nasabah Mampu Yang Menunda-nunda Pembayaran. Bunyinya adalah: 
1. Sanksi yang disebut dalam fatwa ini adalah sanksi yang dikenakan LKS kepada nasabah yang mampu membayar, tetapi menundanunda pembayaran dengan sengaja.

2. Nasabah yang tidak/belum mampu membayar disebabkan force majeur tidak boleh dikenakan sanksi.

3. Nasabah mampu yang menunda-nunda pembayaran dan/atau tidak mempunyai kemauan dan itikad baik untuk membayar utangnya boleh dikenakann sanksi.

4. Sanksi didasarkan pada prinsip ta'zir, yaitu bertujuan agar nasabah lebih disiplin dalam melaksanakan kewajibannya.

5. Sanksi dapat berupa denda sejumlah uang yang besarnya ditentukan atas dasar kesepakatan dan dibuat saat akad ditandatangani.

6. Dana yang berasala dari denda diperuntukan sebagai dana sosial.

Inti dari pasal dan fatwa DSN di atas adalah menjelasakan tentang sanksisanksi yang harus dihadapi bagi pihak yang ingkar janji. Sebagaimana pada perjanjian pembiayaan murabahah No.01057/Pem/m84/02/2011 ini maka Para Tergugat selaku orang yang ingkar janji harus membayar kerugian materil pokok dan sejumlah denda yang telah disepakati. Dan denda tersebut harus dipergunakan sebagai dana sosial.

Selanjutnya, yang menjadi dasar pertimbangan hukum adalah Yurisprudensi Mahkamah Agung RI tanggal 26 februari 1973 No. 793 K/SIP/1972 tentang uang paksa (dwangsom), yang intinya adalah menjelasakan bahwa uang paksa (dwangsom) ini merupakan suatu cara agar seseorang "dipaksa" untuk melaksanakan suatu perbuatan, yaitu dengan menghukumnya membayar sejumlah uang tertentu apabila perbuatan yang "dipaksakan" tidak dilaksanakannya. Dalam hal ini dwangsom tidak dapat mungkin dijatuhkan tanpa hukuman pokok, sebab dwangsom bersifat accesoir (tambahan dan diikatkan dengan perjanjian pokok. Sedangkan tuntutan pada pokok perkara ini adalah untuk menghukum Para Tergugat dengan membayar kerugian materil dan denda berupa pembayaran kepada Penggugat.

Pertimbangan hukum terakhir yang digunakan oleh Hakim adalah Herzien Inlandsch Reglement (HIR). HIR adalah Hukum Acara Perdata yang berlaku di Pengadilan Negeri maupun Pengadilan Agama . Pasal yang digunakan Hakim adalah Pasal 181 ayat (1) HIR. Pasal 181 ayat (1) HIR menjelaskan mengenai hal siapa yang membayar biaya perkara. Bunyi pasal tersebut adalah: 
"Barangsiapa yang dikalahkan akan membayar perkara. Akan tetapi biaya perkata dapat dibebankan bersama-sama terhadapa suami-isteri, keluarga dalam garis lurus, saudara laki-laki atau perempuan, atau keluarga semenda dalam derajat yanng sama, dan juga dalam hal-hal di mana para pihak ada bagian-bagian yang dikalahkan."

Pada pasal ini mengandung arti bahwa pihak yang kalah dalam persidangan harus menanggung beban biaya yang timbul akibat perkara. Para Tergugat merupakan pihak yang kalah, oleh sebab itu mereka berkewajiban membayar biaya perkara tersebut. Namun, dalam perkara ini Para Tergugat tidak pernah lagi hadir menghadap ke muka persidangan, maka guna terpenuhinya asas administrasi peradilan yang baik, semua biaya yang timbul dari perkara ini seluruhnya dibebankan kepada Penggugat.

Berdasarkan analisis yang peneliti telah paparkan di atas, maka peneliti dapat simpulkan bahwa dalam memutus perkara No. 1062/Pdt.G/2016/PA. Tmk, Majlis Hakim menggunakan sumber hukum berupa: Undang-Undang Nomor 7 Tahun 1989 sebagaimana telah dirubah dengan Undang-Undang Nomor 3 Tahun 2006 dan Perubahan kedua dengan Undang-Undang No. 50 Tahun 2009 Tentang Peradilan Agama, Undang-Undang No. 40 Tahun 2007 Tentang Perseroan Terbatas, Kompilasi Hukum Ekonomi Syariah (KHES), Undang-Undang No 21 Tahun 2008 Tentang Perbankan Syariah, Fatwa Dewan Syariah Nasional (DSN), KHUPerdata, dan Herzien Inlandssch Reglement (HIR).

Terhadap penggunaan Pasal 20 KHES. Sebagaimana peneliti ketahui di dalam KHES Pasal 20 ini memiliki 46 ayat, yang seharusnya dapat diperjelas kembali dengan mencantumkan ayat pasal yang berkaitan dengan perkara ini (akad murabahah) Ayat (1) dan (6). Maka dengan demikian, peneliti menyarankan untuk penulisan baik pasal dan ayat pada Undang-Undang dapat diperjelas kembali, guna memberika dasar hukum yang eksplisit.

Pun demikian, peneliti sangat mengapresiasi kepada Hakim yang telah memutus perkara ini. Sebab dalam memutuskan perkara ini, Hakim telah menelaah secara utuh melalui mekanisme beracara di Pengadilan Agama. Melalui UndangUndang No. 50 Tahun 2009 Tentang Peradilan Agama merupakan UndangUndang baru dan merupakan perubahan kedua dari Undang-Undang No. 7 Tahun 1989 sebagaimana perubahan pertama Undang-Undang No. 3 Tahun 2006 Tentang Peradilan Agama yang di dalamnya menyangkut kewenangan absolut Pengadilan Agama yang berwenang memeriksa, memutus, dan menyelesaikan 
perkara ekonomi syariah. Dan juga penggunaan KHES oleh Hakim sebagai sumber hukum utama dalam memutus sengketa ekonomi syariah dan diikuti dengan pertimbangan hukum menggunakan Fatwa DSN dan Undang-Undang yang berkatian dengan ekonomi syariah.

\section{SIMPULAN}

Berdasarkan pada uraian di atas, maka dapat dituliskan beberapa catatan penting, yaitu: persengketaan antara kedua pihak murni kelalaian nasabah selaku debitur yang tak bisa menunaikan kewajibannya, kemudian dalam proses penyelesaiannya di Pengadilan Agama telah sesuai dengan mekanisme beracara di Peradilan Agama sebagaimana tertuang pada Undang-Undang No. 03 tahun 2006 tentang Peradilan Agama dan Undang-Undang No. 21 tahun 2008 tentang Perbankan Syariah. Dasar hukum pertimbangan hakim memutuskan perkara No. 1062/Pdt.G/2016/PA.Tmk adalah Kompilasi Hukum Ekonomi Syariah (KHES), KHUPerdata, Yurisprudensi, Undang-Undang No. 40 Tahun 2007 Pasal 98 Tentang Perseroan Terbatas.

\section{DAFTAR PUSTAKA}

Asyur Abdul Jawad Abdul Hamid. An Nidham Lil Bunuk al Islami, Ala Ma'had al Alamy lil Fikr al Islamy. Cairo, Mesir. 1996.

Cecep Maskanul Hakim. Problematika Penerapan Murabahah Dalam Bank Syariah. Paper. 2004.

Chapra. M. Umer. Sistem Moneter Ilam, Judul Asli: Towards a Just Monetary System. Penerjemah: Ikhwan Abidin Basri. Jakarta: Gema Insani Press dan Tazkia Cendekia. 2000.

Dewan Syariah Nasional MUI dan Bank Indonesia. Himpunan Fatwa Dewan Syariah Nasional MUI. Jakarta: CV. Gaung Persada. 2006.

Fathor Razi. Penyelesaian Sengketa Ekonomi Syariah Di Lingkungan Pengadilan Agama. Tesis yang diterbitkan, UIN Sunan Kalijaga Yogyakarta. 2013.

Fikih. https://id.wikipedia.org/wiki/Fikih diakses tanggal 28 Mei 2018 (Pukul 14:54 WIB)

Harahap. M. Yahya. Segi-Segi Hukum Perjanjian. Bandung: Penerbit Alumni. 1986. Hasil wawancara penulis dengan Bapak Asep Ridwan Hotoya, S.HI., M.Ag. (Hakim Pengadilan Agama Kota Tasikmalaya), pada tanggal 24 Juli 2018 Pukul 08:15 WIB bertempat di ruang Hakim Pengadilan Agama Kota Tasikmalaya. https://dsnmui. 
or.id/ diakses tanggal 28 Mei 2018 (pukul 13:50 WIB). Jimly Asshiddiqie. Penegakan Hukum. 2006. diakses 5 Juni 2018) Kamus KBBI, (1990).

Khuthut Ra'isiyyah fi Al-Iqtishad Al- Islami. Kuait: Maktabat AL-Manar Allslamiyah. 1968.

Listyo Budi Santoso. Kewenangan Pengadilan Agama Dalam Menyelesaikan Sengketa Ekonomi Syariah. (Berdasarkan Undang-Undang Nomor 3 Tahun 2006). 2009. Tesis Program Studi Magister Kenotariatan Universitas Semarang.

Louis Ma'uf. Al Munjid al Lughoh wa al-A'lam, Daar al masyriq, Bairut. 1978. Lubis. Sulaikin dan Marzuki . W. A. Hukum Acara Perdata Peradilan Agama Di Indonesia. Jakarta: Prenada media. 2005.

M. Irfan F. Penyelesaian Sengketa Ekonomi Syariah di Pengadilan Agama (Studi Atas Putusan Pengadilan Agama Cimahi Nomor: 004/Pdt.G/2009?PA.Cmi. ) 2015.

Mardani. Hukum Perikatan Syariah di Indonesia. Jakarta: Sinar Grafika. 2013. Maskufa, Penyelesaian Sengketa Perjanjian Syariah Pada Lembaga Keuangan Syariah. Artikel diakses pada tanggal 24 Mei 2018 di media.neliti.com (pukul 11.18 WIB).

Mujahidi. Ahmad. Prosedur Penyelesaian Sengketa Ekonomi Syariah di Indonesia. Bogor: Ghalia Indonesia. 2010.

Nasution . Mustafa Edwin, dkk. Pengenalan Ekslusif Ekonomi Islam. Jakarta: Prenadamedia Group. 2006.

Ridadi. Ahmad Rizki. Aspek Hukum Dalam Bisnis. Surabaya: Airlangga University Press. 2009.

Rifa'i. Moh. Konsep Perbankan Syariah. Semarang: CV. Wicaksana. 2002.

S.Pradja . Juhaya. Ekonomi Syariah. Bandung: CV Pustaka Setia. 2012

Sami Hasan Hamud. Tathwîr al- A'mâl al-Mashrafiyah Bimâ Yattafiq al-Syarî' ah al-Islâmiyah. Aman: Mathba'ah al-Syarq. 1992.

Satori. Djam'an dan Komariah. Aan. Metodologi Penelitian Kualitatif. Bandung: Alfabeta. 2011.

Satrio. J. Hukum Perikatan, Perikatan Lahir dari Perjanjian. Bandung: Citra Aditya Bakti. 1995. 